\title{
Wolbachia sebagai alternatif pengendalian vektor nyamuk Aedes sp.
}

\author{
Lusiyana $\mathrm{N}^{1}$ \\ ${ }^{1}$ Departemen Parasitologi Fakultas Kedokteran Universitas Islam Indonesia
}

Demam Berdarah Dengue (DBD) adalah penyakit yang disebabkan oleh virus dengue. Virus dengue ditransmisikan kepada manusia melalui perantara vektor yaitu nyamuk Aedes aegypti dan Aedes albopictus (Aedes sp.). Penyakit ini dapat terjadi sepanjang tahun dan meningkat seiring dengan datangnya musim penghujan. Penyakit DBD memiliki mortalitas yang cukup tinggi terutama di negara-negara beriklim tropis dimana banyak faktor yang mendukung perkembangbiakan nyamuk vektor tersebut.

Pengendalian vektor merupakan salah satu upaya dalam menurunkan mortalitas penyakit DBD, karena hingga saat ini belum ditemukan obat maupun vaksin untuk penyakit tersebut. Salah satu upaya pengendalian vektor nyamuk Aedes sp. adalah pengendalian secara biologis menggunakan Wolbachia. Wolbachia merupakan suatu bakteri gram negatif intraseluler yang mampu hidup didalam tubuh nyamuk Aedes sp. Wolbachia mampu mengintervensi masa hidup nyamuk, mengganggu sistem reproduksi nyamuk, dan juga mampu menghambat replikasi virus dengue di dalam tubuh nyamuk. ${ }^{1,2}$

Nyamuk Aedes sp. ber-Wolbachia pertama kali ditebar di Daerah Istimewa Yogyakarta tepatnya di Kabupaten Bantul. Hal ini dipelopori oleh Eliminate Dengue Project (EDP) yang berkerjasama dengan sebuah Universitas di Australia. ${ }^{3}$ Nyamuk Aedes $s p$. yang dilepas di lapangan adalah nyamuk yang sebelumnya telah dikembangbiakkan di laboratorium. Nyamuk laboratorium tersebut diharapkan akan kawin dengan nyamuk Aedes aegypti lokal, dan otomatis menularkan Wolbachia kepada nyamuk lokal. Anak- 
anak nyamuk dari perkawinan tersebut akan membawa bakteri Wolbachia di dalam tubuhnya dan dapat mengurangi transmisi virus dengue. Demikian seterusnya, sehingga diharapkan seluruh nyamuk Aedes sp. di alam akan tertular bakteri wolbachia. ${ }^{3,4}$

Penerapan Wolbachia sebagai pengendali vektor memiliki efek negatif yaitu menghambat proliferasi sel yang berpengaruh terhadap kemampuan hidup nyamuk sehingga Wolbachia dalam tubuh Aedes sp. mampu menurunkan harapan hidup nyamuk dan menurunkan kemampuan hisap nyamuk. ${ }^{4}$ Bakteri Wolbachia juga dapat diturunkan dari seekor nyamuk betina yang mengandung Wolbachia, sedangkan Wolbachia tidak dapat diturunkan dari nyamuk betina yang tidak terinfeksi Wolbachia walaupun telah kawin dengan nyamuk jantan yang mengandung wolbachia karena pola pewarisannya adalah bersifat maternal. ${ }^{1,3}$

Penerapan Wolbachia dalam pengendalian nyamuk menimbulkan pro dan kontra di berbagai kalangan, seperti apakah Wolbachia dapat menginfeksi tubuh manusia, apakah nyamuk hasil kawin silang dengan nyamuk impor tidak berbahaya, dan masih banyak lainnya. Pengendalian vektor menggunakan Wolbachia dapat merupakan salah satu alternatif pengendalian penyakit dengan perantara vektor nyamuk yang cukup efektif, tetapi penerapan Wolbachia di masyarakat harus selalu dipantau secara berkelanjutan untuk mengetahui dampak yang ditimbulkan baik terhadap manusia, nyamuk lokal dan juga ekosistem.

\section{Daftar Pustaka}

1. Bian G, Xu Y, Lu P, Xie Y, Zhiyong X. The endosymbiotic bacterium Wolbachia induces resistance to dengue virus in Aedes aegypti, PloS Pathogens, 2010; 6(4):e1000833.

2. Jeffry JAL. Characterizing the Aedes aegypti Population in a Vietnamese Village in Preparation for a Wolbachia-Based Mosquito Control Strategy to Eliminate Dengue, PLoS Neglected Tropical Diseases, 2009;3(11):e0000552. 
3. Sucahyo N. UGM rintis pemberantasan demam berdarah dengan Wolbachia. 2014. Diunduh 2 Mei 2015. http://www.voaindonesia.com/content/ugm-rintis-pemberantasan-demam-berdarahdengan-wolbachia/1837797.html

4. Frentiu FD, Robinson J, Young PR, McGraw EA, O’Neill SL. Wolbachia-Mediated Resistance to Dengue Virus Infection and Death at the Cellular Level, PLoS ONE, 2010;5(10):e13398. 